\title{
Bacterial carrageenases: an overview of production and biotechnological applications
}

\author{
Prakram Singh Chauhan ${ }^{1} \cdot$ Arunika Saxena $^{2}$
}

Received: 9 May 2016/Accepted: 10 June 2016/Published online: 23 June 2016

(c) The Author(s) 2016. This article is published with open access at Springerlink.com

\begin{abstract}
Carrageenan, one of the phycocolloids is a sulfated galactan made up of linear chains of galactose and 3,6-anhydrogalactose with alternating $\alpha-(1 \rightarrow 3)$ and $\beta$ $(1 \rightarrow 4)$ linkages and further classified based on the number and the position of sulfated ester(s); $\kappa-, 1-$ and $\lambda$ carrageenan. Enzymes which degrade carrageenans are called $\mathrm{k}$-, $1-$, and $\lambda$-carrageenases. They all are endohydrolases that cleave the internal $\beta-(1-4)$ linkages of carrageenans yielding products of the oligo-carrageenans. These enzymes are produced only by bacteria specifically gram negative bacteria. Majority of the marine bacteria produce these enzymes extracellularly and their activity is in wide range of temperature. They have found potential applications in biomedical field, bioethanol production, textile industry, as a detergent additive and for isolation of protoplast of algae etc. A comprehensive information shall be helpful for the effective understanding and application of these enzymes. In this review exhaustive information of bacterial carrageenases reported till date has been done. All the aspects like sources, production conditions, characterization, cloning and- biotechnological applications are summarized.
\end{abstract}

Keywords Carrageenan - Bacterial carrageenase · Glycoside hydrolase $\cdot$ Biotechnological applications

Prakram Singh Chauhan

drprakramsingh@gmail.com

1 Faculty of Pharmacy and Pharmaceutical Sciences, Monash University Parkville Campus, 381, Royal Parade, Melbourne, VIC 3052, Australia

2 Department of Chemistry, Samrat Prithviraj Chauhan Government College, Beawar Road, Ajmer, Rajasthan, India

\section{Introduction}

Hydrocolloids can be defined as substances that interact with water to form colloid systems. Hydrocolloid polysaccharides (agar, alginates and carrageenans) have significant importance, both technologically and economically, since they are used in the various biotechnological industries due to their distinct physico-chemical properties (Knudsen et al. 2015; Zhu and Ning 2016; Xiao et al. 2016).

Carrageenans are commercially important hydrophilic colloids (water soluble gums) which occur as matrix material in numerous species of red seaweeds [comprise up to $50 \%$ dry weight (Rhodophyta)] wherein they serve a structural function analogous to that of cellulose in land plants. They are a group of biomolecules composed of linear polysaccharide chains with sulphate half-esters attached to the sugar unit. It exists in different forms depending on the number of sulphate substituents per disaccharide unit: one in $\kappa$-carrageenan, two in 1 -carrageenan and three in $\lambda$-carrageenan. These properties allow carrageenans to dissolve in water, form highly viscous solutions, and remain stable over a wide $\mathrm{pH}$ range (Ruiter and Rudolph 1997; Yao et al. 2014; Liu et al. 2016).

Microbial enzymes which hydrolyze hydrocolloids have drawn considerable interest recently because enzymatic degraded products of carrageenan is still in infancy compared to that of other hydrocolloids such as agar, alginate etc. Enzymes which degrade carrageenans are called k-, 1-, and $\lambda$-carrageenases. They all are endohydrolases that cleave the internal $\beta-(1-4)$ linkages of carrageenans yielding products of the oligo-carrageenans. Oligo-carrageenan produced by the action of microbial enzymes can be more advantageous than produced by acid hydrolysis because enzymes are highly specific to their substrates and 
they generate oligo-derivatives are uniform in molecular weights (Yao et al. 2014).

The oligosaccharides derived from carrageenan have been shown to exhibit antitumor, anti viral activity which indicated that oligo-carrageenan could possess significant potential for biomedical and physiological applications ( $\mathrm{Li}$ et al. 2014a, b). In addition to this carrageenase have a various important application such as bioethanol production, textile industry, as a detergent additive and for isolation of protoplast of algae etc.

Due to their versatile industrial applicability, interest has greatly increased in carrageenases during the past decade (Necas and Bartosikova 2013). A number of carrageenases from various organisms are being reported, cloned and studied at molecular level. In this review, information on carrageenases from most of the microorganisms currently reported have been compiled in terms of the production conditions, enzyme properties, gene cloning and potential industrial applications.

\section{Carrageenan occurrence and structure}

Majority of the seaweeds that produce carrageenan as their main cell-wall material belong to the red algae, or Rhodophyta. The carrageenans are extracted from the carrageenophyte red seaweed genera Kappaphycus, Gigartina, Eucheuma, Chondrus, and Hypnea, in which the carrageenans comprise up to $50 \%$ of the dry weight (Knudsen et al. 2015). K-Carrageenan is mostly extracted from Kappaphycus alvarezii, known in the trade as Eucheuma cottonii, while 1-carrageeman is predominantly produced from Eucheuma denticulatum, also known as Eucheuma spinosum. $\lambda$-Carrageenan is obtained from seaweeds within the Gigartina and Chondrus genera, which as sporophytic plants produce $\lambda$-carrageenan while they make a $\kappa /$-hybrid as gametophytic plants (Van De Velde et al. 2001). These $\kappa / 1$-hybrid type carrageenans, also known as "kappa-2" or "weak-gelling kappa carrageenans", consist of mixed polysaccharide chains containing both $\kappa$ - and 1 -units and range from almost pure 1 -carrageenan to almost pure $\kappa$ carrageenan (Table 1).

The seaweed is dried quickly to prevent degradation, and is then baled for shipment to processing facilities. The seaweed is repeatedly washed to remove gross impurities such as sand, salt, and marine life, and then undergoes a hot alkali extraction process, releasing the CG from the cell. Once CG is in a hot solution, it undergoes clarification and then is converted to powder (Rowe et al. 2009). Meanwhile, extraction parameters (such as temperature, $\mathrm{pH}$, duration) and alkaline pre-treatment duration have important effects on the chemical structure and gelling properties (Hilliou et al. 2006).
Carrageenan is a high molecular mass material $(>100 \mathrm{kDa})$ with a high degree of polydispersity. Carrageenans are hydrophilic sulfated linear galactans that mainly consist of D-galactose and 3,6-Anhydro-D-galactose (3,6-AG) units bound together with alternating $\alpha-1,3$ and $\beta$ 1,4 linkages. The 3 -linked units occur as the 2 -and 4-sulfate, or unsulfated, while the 4-linked units occur as the 2-sulfate, the 2,6-disulfate, the 3,6-anhydride, and the 3,6anhydride-2-sulfate. Sulfation at C3 apparently never occurs. Except the galactose and sulfate, other carbohydrate residues (for example xylose, glucose and uronic acids) and substituents (for example methyl ethers and pyruvate groups) are present in carrageenans (Michel et al. 1997; Knudsen et al. 2015) (Fig. 1).

This base structure is consistent in the three main commercially used carrageenans, $\kappa$-, $1-$, and $\lambda$-carrageenan. $\kappa$-Carrageenan has one sulfate ester, while 1 -and $\lambda$-carrageenan contain two and three sulfates per dimer, respectively (Fig. 1). The number and position of ester sulfate groups as well as the content of 3.6-AG influence the properties of different carrageenans. Higher levels of ester sulfate mean lower solubility temperature and lower gel strength. Kappa type carrageenan has an ester sulfate content of about 25-30\% and a 3,6-AG content of about 28-35\%. Iota type carrageenan has an ester sulfate content of about $28-30 \%$ and a 3,6-AG content of about 25-30\%. Lambda type carrageenan has an ester sulfate content of about 32-39\% and no content of 3,6-AG. Considering that each natural carrageenan is a complex galactose-based polysaccharide that has different quantities of sulphate esters at different positions and with different distributions, the term disaccharide repeating unit refers to the idealized structure (Campo et al. 2009).

\section{Microbial carrageenanolytic system}

\section{Enzymatic hydrolysis of carrageenan}

Due to the complex chemical structure of carrageenan and specific cleavage of linkages in the backbones of carrageenan polymers, specific enzymes are required for the respective structures without the risk of modification of the native structure. Enzymes, which degrade carrageenans, are called $\kappa$-carrageenases (EC 3.2.1.83), 1-carrageenases (EC 3.2.1.157), and $\lambda$-carrageenases (EC 3.2.1.162). They all are endohydrolases that cleave the internal $\beta-(1-4)$ linkages of carrageenans yielding oligogalactans of either neocarrabiose or neoagarobiose series (Fig. 2) (Barbeyron et al. 2000). It was reported that $\kappa$-carrageenases and 1 carrageenases degrades carrageenan by hydrolyzing the $\beta$ (1-4) [breaking internal linkages rather than hydrolyzing units from the ends] linkages to a series of homologous, 
Table 1 Chemical structure and properties of different carrageenans

\begin{tabular}{|c|c|c|c|c|c|c|c|}
\hline \multirow[t]{2}{*}{ Polysaccharide } & \multirow[t]{2}{*}{ Sources } & \multicolumn{2}{|c|}{ Backbone made up of alternating units } & \multirow{2}{*}{$\begin{array}{l}\text { No. of } \\
\text { sulfate } \\
\text { ester }\end{array}$} & \multicolumn{3}{|l|}{ Properties } \\
\hline & & A & B & & Solubility & $\begin{array}{l}\text { Gel } \\
\text { formation }\end{array}$ & Viscosity \\
\hline$\kappa$-Carrageenan & $\begin{array}{l}\text { Kappaphycus } \\
\text { alvarezii }\end{array}$ & $\begin{array}{l}\text { 3,6-Anhydro-D- } \\
\text { galactose }\end{array}$ & $\begin{array}{l}\text { D-Galactose } \\
\text { 4-sulfate }\end{array}$ & One & Hot solution & $\begin{array}{l}\mathrm{KCl} \\
\text { promote } \\
\text { gelling }\end{array}$ & Low \\
\hline ı-Carrageenan & $\begin{array}{l}\text { Eucheuma } \\
\text { denticulatum }\end{array}$ & $\begin{array}{l}\text { 3,6-Anhydro-D- } \\
\text { galactose-2- } \\
\text { sulfate }\end{array}$ & $\begin{array}{l}\text { D-Galactose } \\
\text { 4-sulfate }\end{array}$ & Two & $\begin{array}{l}\text { Soluble in cold or hot } \\
\text { aqueous solution }\end{array}$ & $\begin{array}{l}\mathrm{Ca}^{2+} \\
\quad \text { promote } \\
\text { gelling }\end{array}$ & High \\
\hline$\lambda$-Carrageenan & $\begin{array}{l}\text { Gigartina and } \\
\text { Chondrus } \\
\text { genera }\end{array}$ & $\begin{array}{l}\text { D-galactose-2,6- } \\
\text { disulfate }\end{array}$ & $\begin{array}{l}\text { D-galactose, D- } \\
\text { galactose-2- } \\
\text { sulfate }\end{array}$ & Three & $\begin{array}{l}\text { Soluble in cold or hot } \\
\text { aqueous solution }\end{array}$ & Non-gelling & $\begin{array}{l}\text { High/ } \\
\text { medium }\end{array}$ \\
\hline
\end{tabular}

Fig. 1 Structure of kappa, iota and lambda carrageenans
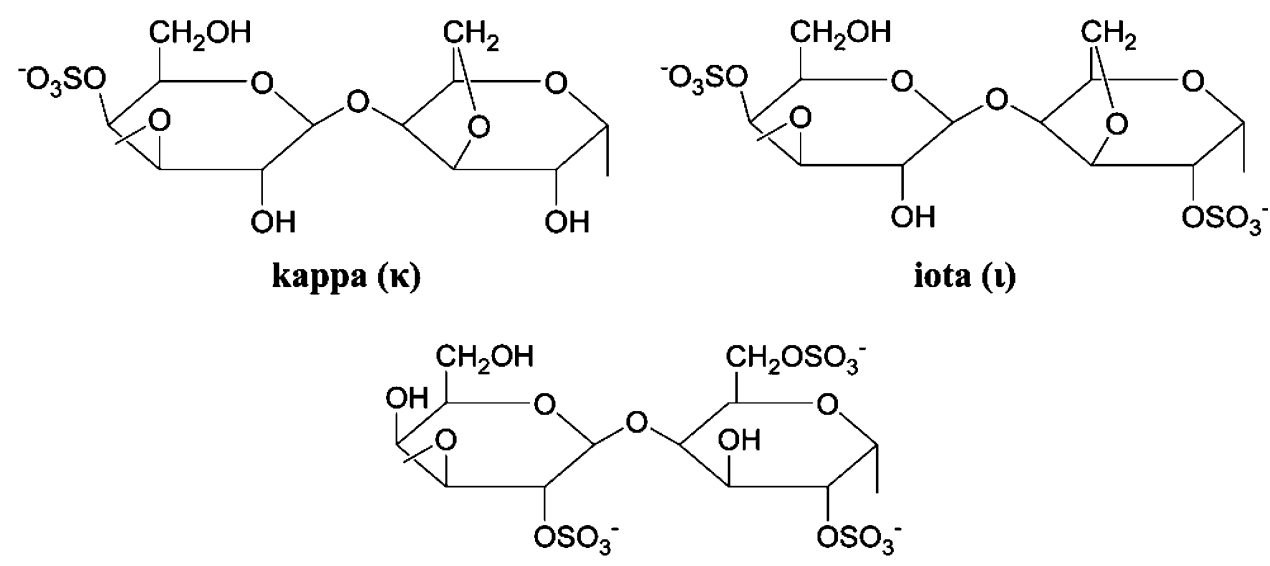

lambda $(\lambda)$

Fig. 2 Schematic representation of two disaccharide-repeating units of $\kappa$-carrageenan having reducing as well as non reducing ends. Carrageenan cleavage site are indicated by arrow (Michel et al. 2001a)

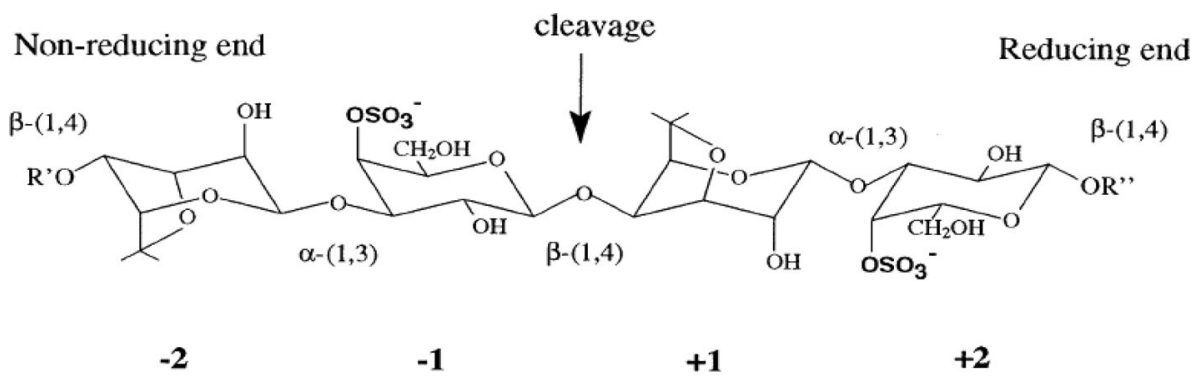

even-numbered oligosaccharides. Although, both enzymes are processive, in which the enzyme does not dissociate from the substrate and instead slides along the polysaccharide, cleaving all possible bonds (DP4s and DP2s). In contrast, $\lambda$-carrageenase cleaves internal linkages more randomly manner, resulting in higher amounts of DP6s (and possible other higher DPs as products) compared to the products from $\kappa$ - and 1 -carrageenase hydrolysis. Since these hydrolases display strict substrate specificity, they obviously recognize the sulfation pattern on the digalactose repeating unit. Digestion by carrageenases generates oligogalactans of various sizes, most likely carbohydrates with a degree of polymerization (DP) of 2,4 , and 6 . The reason for the production of different DPs is a result of the heterogenous carrageenan structure and the mechanisms that the enzymes follow. The alternating $\alpha-1,3$ and $\beta-1,4$ linkages in the carrageenans results in successive $\beta-1,4$ linkages to be in opposite orientations and hence only every second disaccharide is in the right position for cleavage (Michel et al. 2001a; Guibet et al. 2007; Lemoine 
et al. 2009). A chain length of four sugar residues is required for the binding of carrageenases to ensure hydrolysis. The substrate binding surface can be split into different subsites. Subsites are numbered from $-n$ to $+n$ ( $n$ being an integer) from nonreducing to reducing ends of the mannan substrate, respectively (Davies et al. 1997). Cleavage of the glycosidic bond occurs between subsite +1 and -1 (Fig. 2). Oligo-carrageenan produced by the action of microbial enzymes can be more advantageous than produced by acid hydrolysis because enzymes are highly specific to their substrates and they generate oligo-derivatives are uniform in molecular weights (Yao et al. 2014).

\section{Reaction mechanism of carrageenan degrading enzymes}

Different carrageenases exhibit different mechanism for the hydrolysis polymer. $\kappa$-Carrageenases hydrolyse their substrates by a retaining mechanism which occurs via double-displacement reaction (Fig. 3) (Chauhan et al. 2012, 2014a; Chauhan and Gupta 2016). The key amino acids involved in the retaining mechanism reaction are two catalytic carboxylate residues that exist at opposite sides of sugar plane. The enzymes in this mechanism works in tandem involving two steps i.e. glycosylation and deglycosylation (Chauhan et al. 2015). In the first step of double displacement mechanism, it facilitates the departure of leaving group by donating proton to the glycosyl oxygen atom. Simultaneously a second carboxylate moiety facilitates the nucleophilic attack on the anomeric carbon to form glycosyl-enzyme intermediate (Fig. 3). In the second step, the deprotonated acid/base functions as a general base which activates nucleophile. This activated nucleophile then cleaves the glycosyl enzyme complex (Fig. 3). In spite of wide array of $\mathrm{GH}$, hydrolysis of glycosidic bond is generally catalyzed by either glutamate (Glu) or Aspartate (Asp).

1-Carrageenases hydrolyse their substrate by inverting mechanism (Fig. 4), In this, there is an inversion of the anomeric configuration of the starting material. Here, the two crucial carboxylic residues act as general acid and base catalysts and these groups are circa $10.5 \AA$ apart from each other. It this specific case, this distance is larger than in retaining GHs because the substrate and the water

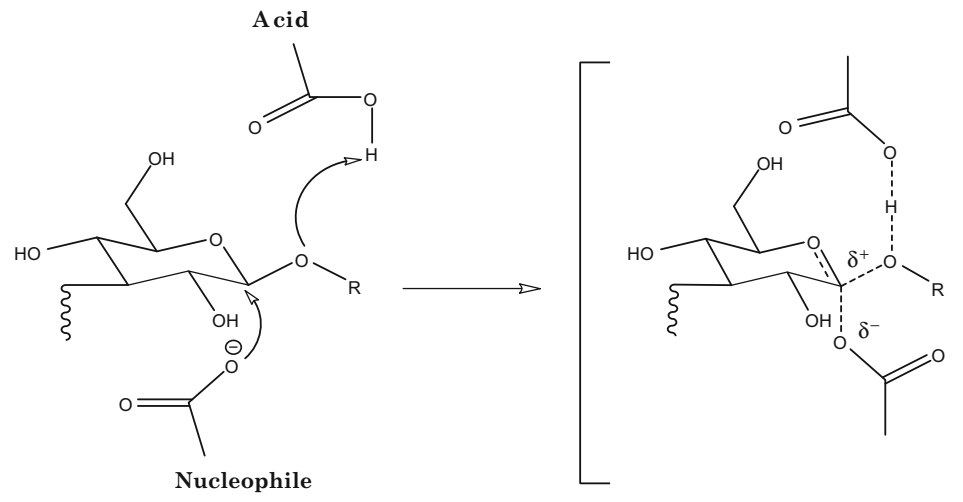

Glycosylation

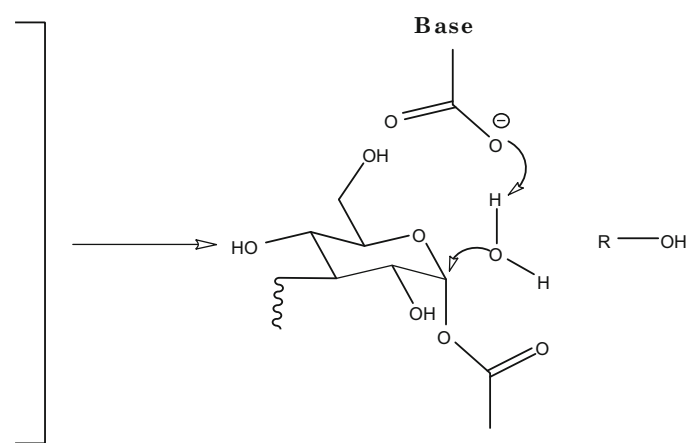

Nucleophile

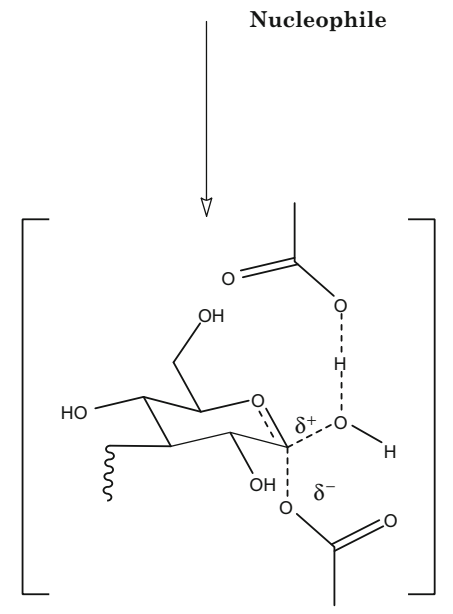

Deglycosylation

Fig. 3 Retaining mechanism for the degradation of carrageenan by $\kappa$-carrageenases via double displacement reaction (Chauhan et al. 2012) 


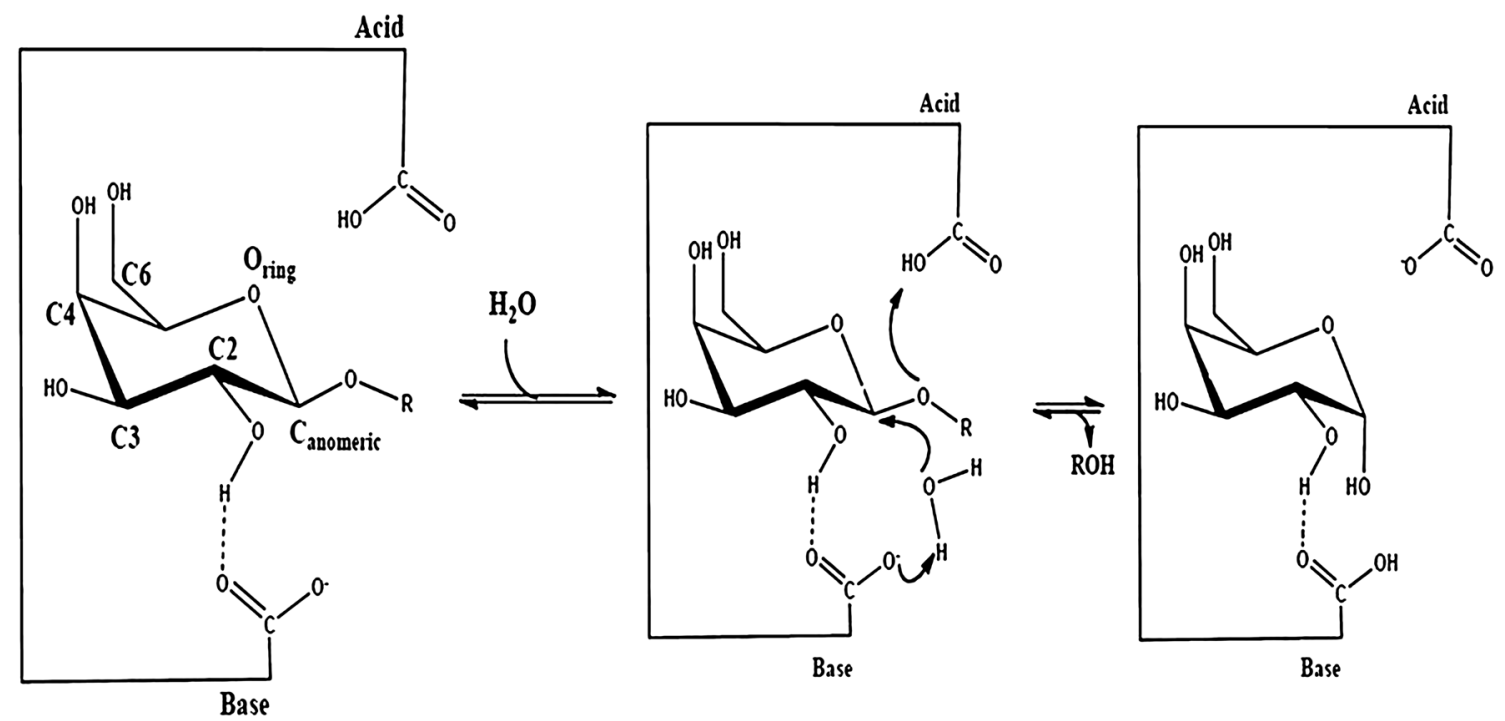

Fig. 4 Inverting mechanism for the degradation of carrageenan by -carrageenases via single displacement reaction (Bras et al. 2012)

molecule must be present simultaneously in the active site of the enzyme during the hydrolytic process. Figure 4 shows the proposed mechanism of action for inverting GHs, which occurs via a single-displacement type of mechanism. In this case, one of the carboxylate residues protonates the scissile glycosidic oxygen atom while the other coordinates the nucleophile (i.e., the water molecule) to assist its deprotonation and in this way completes the hydrolysis reaction (Michel et al. 2001b, 2003).

\section{Assay methods for carrageenases}

Numerous screening methods exist for detecting carrageenanolytic activity in microorganisms. A solid medium giving fast assays is useful for the direct measurement and isolation of carrageenan degrading organisms from natural substrates. Common screening techniques used for the detection of carrageenan degrading enzymes involve plate assays where the individual polymer, is added into the basal growth medium. The formation of analogous hydrolases is indicated by the plate depression-forming activity or liquefaction or clearing of the opaque medium as the substrate is hydrolyzed by the enzymes formed by the growing colonies (Henares et al. 2010). In addition to this by flooding the solid medium with $10 \%$ cetylpyridinium chloride, the colonies with clear zones against a white background is another way to find out carrageenan-degrading microorganisms (Ohta and Hatada 2006). Similar to this enzyme is kept in a well cut in an agar medium containing a carrageenan substrate. The agar surface commonly swaps with a Lugol's solution (Potassium iodide and Iodine) to develop the zones of enzyme activity near the cup. The width of the cleared zone is quantify with calipers and recorded. Width is converted to enzyme activity using a dilution of the enzyme and plotting zone width with respect to the log of enzyme concentration (Kang and Kim 2015).

In liquid assay method carrageenase activity is determined using carrageenan as a substrate. In viscometric method, flow time of the digest (enzyme + substrate) was determined at once and also at regular intervals after putting the viscometer in water bath at particular temperature. One viscometric unit of enzyme activity was defined as the amount of enzyme which would reduce the specific viscosity of the substrate by $50 \%$ (Mclean and Williamson 1979).

In spectrophotometric method reducing sugar released from the substrate by the action of enzyme was determined by Somogyi-Nelson procedure (Somogyi 1952). Here addition of alkaline copper sulfate was added which helpful to stop the reaction between enzyme and substrate. In Dinitrosalicylic acid (DNSA) method reducing sugar released by the action of enzyme on substrate was quantified with Dinitrosalicylic acid (DNSA) reagent (Miller 1959) by taking the absorbance at $560 \mathrm{~nm}$ whereas in Kidby method reaction mix were incubate with Kidby solution $\left(1 \% \mathrm{Na}_{2} \mathrm{CO}_{3}\right.$ and $0.03 \%$ potassium hexacyanoferrate III). Color development was achieved by placing tubes in a water bath $100^{\circ} \mathrm{C}$. Finally, the spectral absorbance of samples at $420 \mathrm{~nm}$ was measured (Kidby and Davidson 1973). One unit of $\kappa$-carrageenase activity was defined as the amount of enzyme needed to release $1 \mu \mathrm{mol}$ reducing sugars (D-galactose equivalent) per min.

In neocuproine method, assay mixture was incubated for particular time and temperature followed by the addition of $1 \mathrm{ml}$ of alkaline copper reagent $\left(4 \% \mathrm{Na}_{2} \mathrm{CO}_{3}, 1.6 \%\right.$

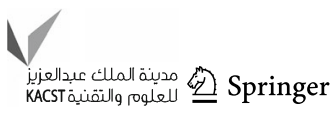


Glycine and $0.045 \% \mathrm{CuSO}_{4}$ ) to stop the reaction. After that $1 \mathrm{ml}$ of $5 \mathrm{mM}$ Neocuproine- $\mathrm{HCl}$ reagent was added to the tube and was kept in a boiling water bath. It was necessary to add ethanol $(50 \% \mathrm{v} / \mathrm{v})$ to the reaction mixture before measuring the absorbance. One unit of the enzyme activity was defined as the amount which liberated $1 \mu \mathrm{mol}$ galactose equivalent per minute under the assay conditions (Dygert et al. 1965).

\section{Carrageenases classification and structural characteristics}

Based on amino acid sequences, these enzymes belong to distinct glycoside hydrolase $(\mathrm{GH})$ families. Although the various carrageenans are chemically rather close, but the respective GHs that degrade different types of carrageenans do not belong to the same family. $\kappa$-Carrageenases belong to GH16 (family 16 of the GHs) (Barbeyron et al. 1994, 1998), a polyspecific family which encompasses at least eight different enzymatic activities, including $\beta$-agarases ((http://www.cazy.org/) (Coutinho and Henrissat 1999; Cantarel et al. 2009). Phylogenetic analysis investigations demonstrated that family GH16 enzymes have evolved from a common ancestor and that $\kappa$ carrageenases have likely emerged from the $\beta$-agarase branch (Jam et al. 2005) and they belong to clan GH-B. $\kappa-$ Carrageenases hydrolyse $\beta-(1 \rightarrow 4)$ glycosidic linkages with retention of the anomeric configuration (Potin et al. 1995). 1-Carrageenases define the unrelated family GH82 (Michel et al. 2006; Rebuffet et al. 2010), while $\lambda$-carrageenases constitute a new GH family, although it has not been yet classified in the carbohydrate-active enzymes (CAZy) database (Barbeyron et al. 1998). The $\kappa$-carrageenase belongs to this family adopts a typical $\beta$-jellyroll fold (polypeptide chain is wrapped around a barrel core like a jelly roll) whereas 1 -carrageenases carry $\beta$-helix in 3D-structure (Guibet et al. 2007).

Carrageenases have been poorly characterized from a structural point of view. Till now three dimensional structure of only two carrageenase i.e., $\kappa$-carrageenase (CgkA) from Pseudoalteromonas carrageenovora and 1carrageenase (CgiA_Af) from Alteromonas fortis has been solved. Both of the enzymes displays a tunnel-shaped active site suggesting a processive mode of action in which the enzyme does not dissociate from the substrate and instead slides along the polysaccharide, cleaving all possible bonds. The $\kappa$-carrageenan chain is composed of alternating neutral and negatively charged sugars (DA and G4S, respectively). To accommodate the dual nature of its substrate, $\kappa$-carrageenase features in its active site both conserved aromatic and basic residues which are predicted to interact with DA and G4S moieties, respectively (Michel et al. 2001b) whereas carrageenan which consists of only negatively charged sugars (DA2S and G4S) is recognized by $\kappa$ - and 1 -carrageenase essentially through ionic interactions between its sulfate groups and several conserved arginine residues of the protein (Michel et al. 2003). Studies on $\kappa$ - and 1 -carrageenases have provided some insight into sulfated polysaccharide-protein interactions; but the chemical complexity of sulfated polysaccharides is a patent obstacle to such analyses and researcher looking for better structural characterization (Michel et al. 2001a).

However, they all hydrolyze carrageenan substrates, but these carrageenases do not share significant sequence homology. Although they share some common binding site for ions which helpful in stabilizing the enzyme. Here the three dimensional structure of 1-carrageenase (CgiA_Af) from Alteromonas fortis is shown in Fig. 5. The enzyme folds into a right-handed parallel $\beta$-helix of 10 complete turns with flanked by two domains ( $\mathrm{A}$ and $\mathrm{B}$ ) in the C-terminal region. Glu245, Asp247, or Glu310, in the cleft of the enzyme, are proposed as candidate catalytic residues. The protein contains one sodium and one chloride binding site and three calcium binding sites shown to be involved in stabilizing the enzyme structure. The crystallographic structure of this enzyme was also solved in the presence of substrate oligocarrageenans, where a tetrasaccharide and a disaccharide have been located in subsites +4 to +1 and -3 to -4 , respectively (Michel et al. 2001b). The A. fortis iotase hydrolyzes the $\beta$ - $(1-4)$ bond by an inverting mechanism and produces neo-l-carratetraose and neo-t-carrahexaose as end products. Like the 1 -carrageenases, $\kappa$ -

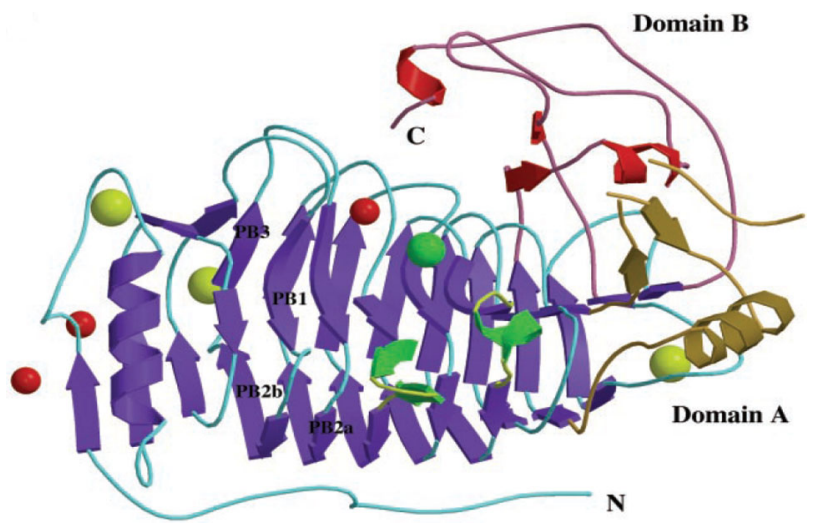

Fig. 5 Three dimensional structure of CgiA_Af carrageenase from Alteromonas fortis. The enzyme assembly contains domains, antiparallel sheet, helix and ions which are represented with different color (Michel et al. 2001b). Domain A (Gold), Domain B (Red) and helix core (Blue) are structural domains containing mainly $\beta$-sheets contains the catalytic center. Small T1 extension, containing an antiparallel sheet $(\beta 16-\beta 17)$ and $\alpha$-helix $(\alpha 2)$, is shown in green. Sodium, calcium, and chloride ions are represented by red, yellow, and green spheres, respectively involved in stabilizing the enzyme structure 
carrageenases are endohydrolases, breaking internal linkages rather than hydrolyzing units from the ends. Also, both enzymes are processive, hydrolyzing several units in succession. In contrast, $\lambda$-carrageenase cleaves internal linkages randomly (Michel et al. 2003; Guibet et al. 2007; Knudsen et al. 2015).

\section{Sources of carrageenases}

Carrageenases have been produced from marine bacteria that belong to two distantly related lineages, Proteobacteria and Bacteroidetes, although most of the isolates belong to the former group. Carrageenases appears to carry out different functions, depending on the producing organism. Carrageenases from bacteria are often employed in the degradation of polysaccharides particularly carrageenan from marine rhodophytes, are major raw materials for a number of industries worldwide. In this regard, studies on important carrageenan degraders reported in the recent years are listed in Table 2. Among bacteria, degradation is mostly confined to Gram negative, mainly various Pseudoalteromonas, Cellulophaga, Pseudomonas, Cytophaga, Tamlana, Vibrio, Catenovulum, Microbulbifer, Zobellia, Alteromonas (Shangyong et al. 2013; Yao et al. 2013; Ziayoddin et al. 2014; Mou et al. 2004; Feixue et al. 2010; Li et al. 2015; Hatada et al. 2011; Liu et al. 2013; Michel et al. 2001b; Zhu and Ning 2016). However, some Gram positive bacteria like Bacillus sp. and Cellulosimicrobium have also been reported to produce carrageenase (Kang and Kim 2015; Youssef et al. 2012). Till date no fungal species is identified which are able to produce carrageenase which is going to be very hot area in near future for exploring the microbial diversity.

\section{Production conditions and properties}

A number of bacterial species are capable of degrading carrageenan with the help of carrageenases enzyme which are mainly inducible and extracellular, however, some intracellular report are also available (Potin et al. 1995; Dyrset et al. 1997; Liu et al. 2011, 2014; Beltagy et al. 2012). It is further proposed that major and minor repeat units (dimeric units) produced from the natural polysaccharide by the action of carrageenase can act as inducer for 1-, $\kappa-$, and possibly other carrageenases (Bellion et al. 1982). Other substrates like, nutrient broth and red sea weed powder have also been practiced for the same purpose, since they offer significant benefit due to their cheaper cost and abundant availability (Li et al. 2014a, b; Kang and Kim 2015). Interestingly, it was found that various simple sugars (fructose, glucose, galactose, lactose, sucrose, mannose, maltose) did not induce carrageenase production in medium and they shows catabolite repression effect. Infact co-supplementation of simple sugars with carrageenan found to decrease the production slightly. Although the growth of bacteria was increased in the medium co-supplemented with glucose, fructose or maltose. This may be due to rapid utilization of these simple sugars by the bacterium resulting in an increase in cell mass by vigorous growth (Ziayoddin et al. 2014; George et al. 2014a, b; Sondhi et al. 2015).

The production of carrageenases are greatly influenced by nutritional and physicochemical factors, such as time, optimum temperature, optimum $\mathrm{pH}$, carbon and nitrogen sources, inorganic salts, agitation and dissolved oxygen concentration (Ziayoddin et al. 2012). Various microbes require different incubation times for maximum carrageenases production. It ranges from $12 \mathrm{~h}$ in Bacterium 1 (Greer and Yaphe 1984) to 14 days in Bacillus sp. SYR4. (Kang and Kim 2015). Temperature and pH, giving maximum yield, correspond with the optimal conditions for the growth of the organism. Similar to other metabolic enzymes, optimum carrageenase production in bacteria is in the neutral temperature (Zhou et al. 2008; Feixue et al. 2010; Ma et al. 2013) with the exception of Bacillus sp. Lc50-1 which require $55^{\circ} \mathrm{C}$ for production ( $\mathrm{Li}$ et al. 2014a, b).

Carrageenases have been produced by submerged fermentation in most of the studies (Sarwar et al. 1983a, b, 1987; Youssef et al. 2012; Ziayoddin et al. 2014). However, few attempts have been made for the production of mannosidases by solid state fermentation (SSF). Ziayoddin et al. (2012) have used agro wastes for the enhanced production of carrageenases by SSF. Among them wheat bran induced the production of this enzyme more with enzyme activity of $7.44 \mathrm{Ug}^{-1}$. The production of carrageenase has been increased many fold by optimization of the parameters using response surface methodology such as in case of Cellulosimicrobium cellulans $\kappa$-carrageenase activity to about 2.3 times higher than that obtained from the basal medium (Youssef et al. 2012) whereas in Pseudomonas elongate, 32-fold increase in $\kappa$-carrageenase production was achieved as compared to initial by statistical optimization method (Khambhaty et al. 2007a). Ostgaard et al. (1993) successfully grow Pseudomonas carrageenovora in stirred-tank fermentor (14 L) for scaledup. Interestingly improved production $\left(630 \mathrm{Uml}^{-1}\right)$ of the enzyme carrageenase was obtained by starting bacterial growth on a cheap carbon source (lactose) and adding small amounts of carrageenan $(0.15 \%)$ to initiate enzyme production. Similar to this Dyrset et al. (1997) showed the role of casamino acid $\left(3.5 \mathrm{gl}^{-1}\right)$ in fed batch fermentation of Pseudomonas carrageenovora NUMB 302 and significantly achieved increase in enzyme activity by 2.6 times $\left(84,000 \mathrm{Uml}^{-1}\right)$. 


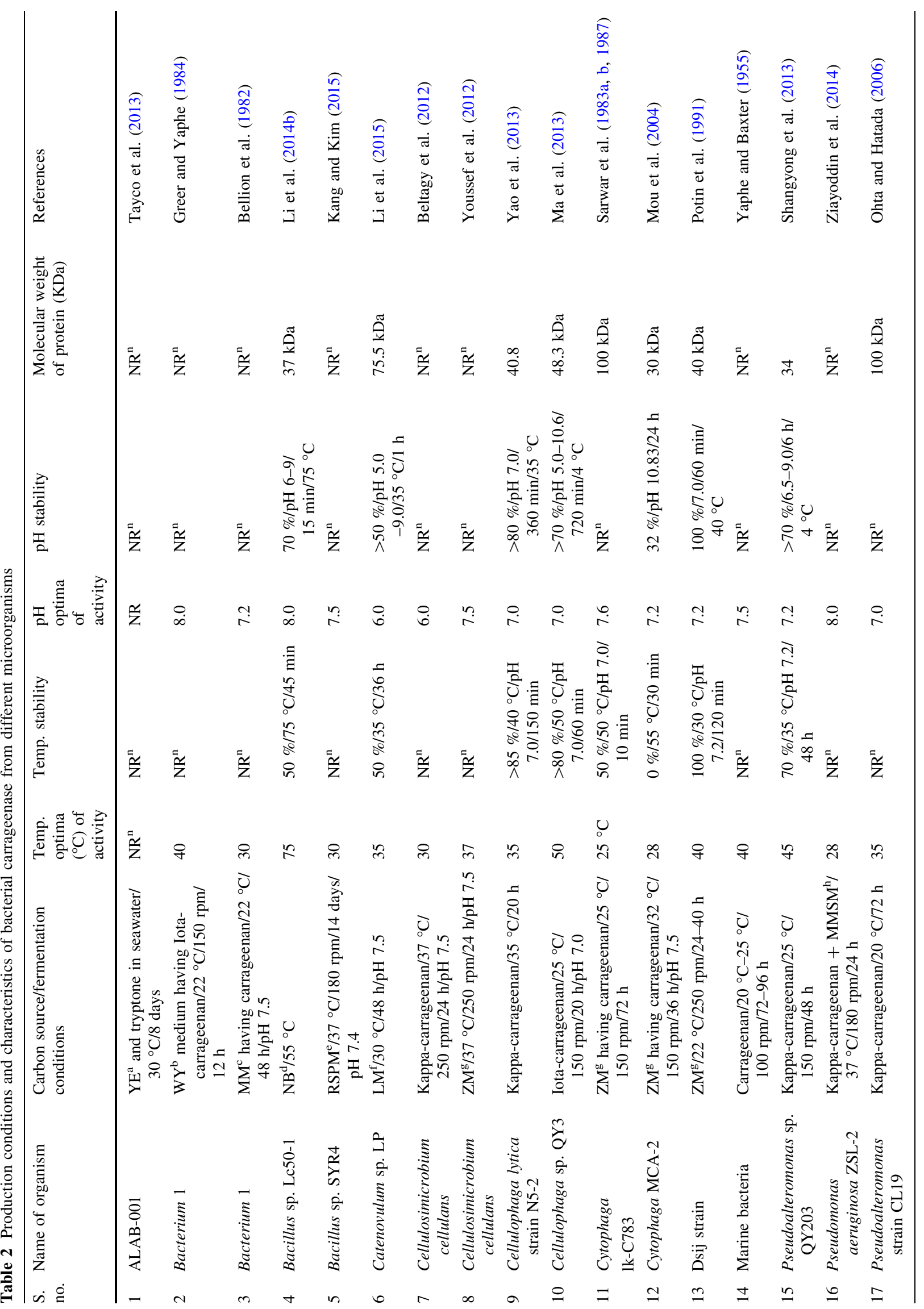




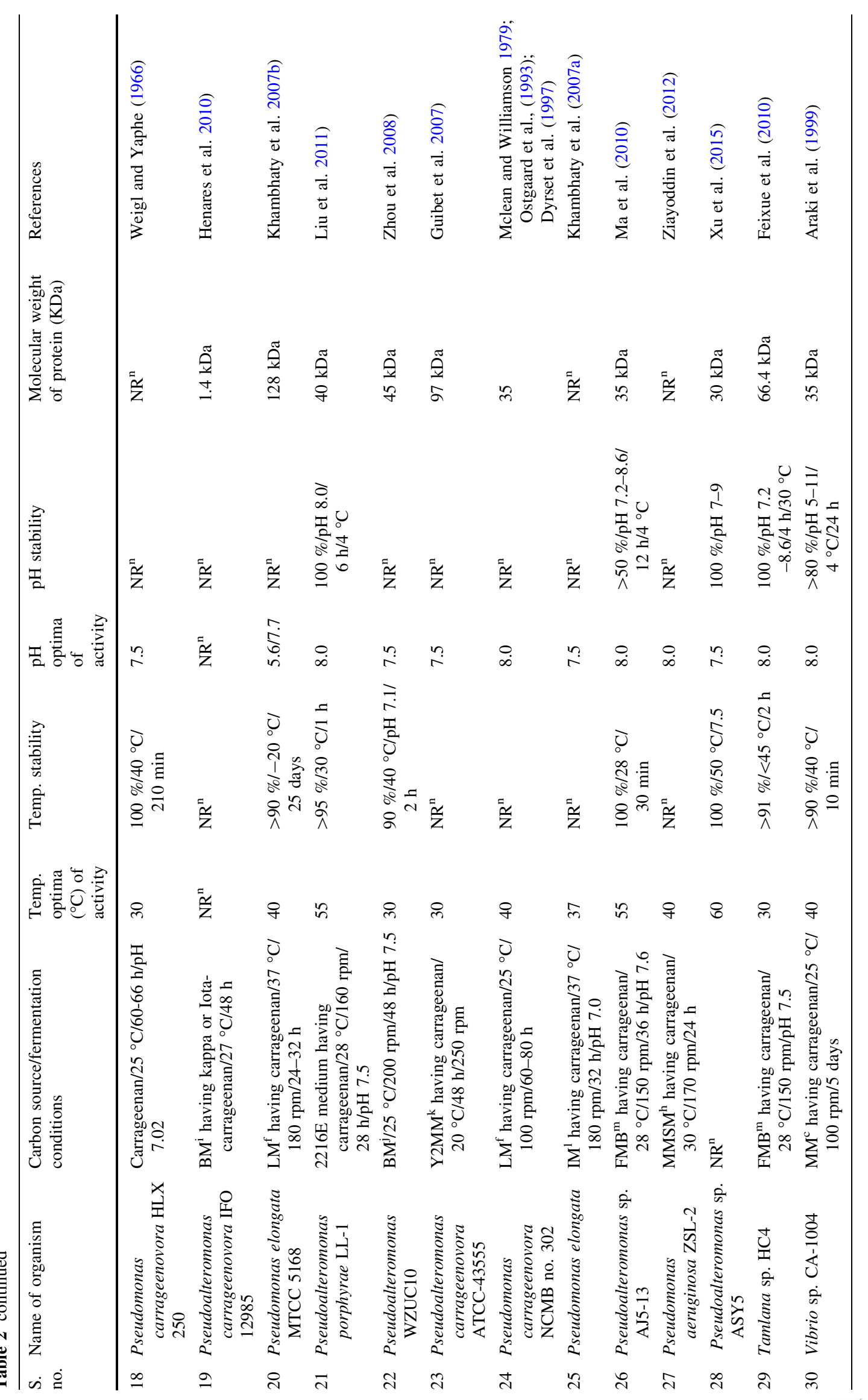




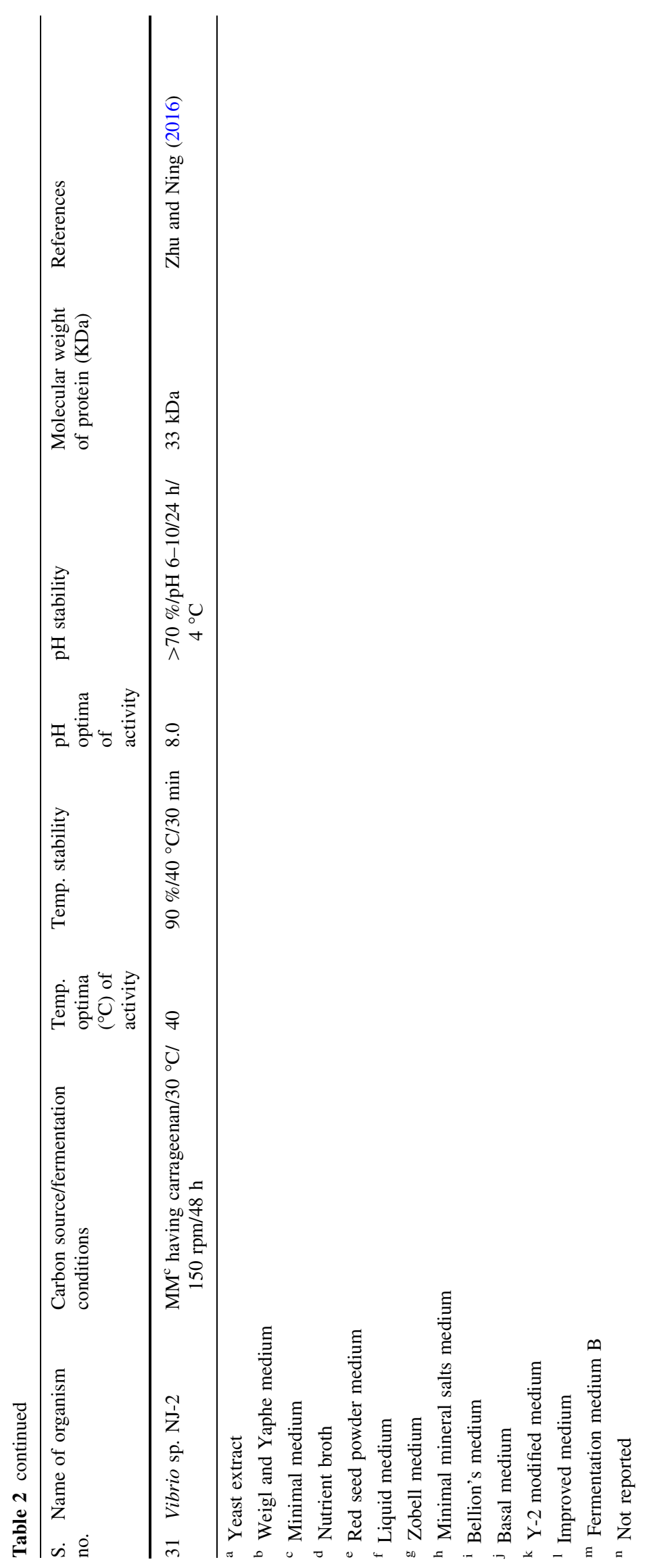


A comprehensive comparison of the characteristics of bacterial carrageenases (Table 2) it was observed that they can operate in a wide temperature range $\left(25-75^{\circ} \mathrm{C}\right)$ (Sarwar et al. 1983a, b; Mou et al. 2004; Li et al. 2014a, b). Most of them have temperature optima from 30 to $40{ }^{\circ} \mathrm{C}$. Optimum $\mathrm{pH}$ for their activity varies from 5.6 to 7.5 (Khambhaty et al. 2007b; Guibet et al. 2007; Kang and Kim 2015) with carrageenases from genus of Pseudomonas having their optimal activity in mild alkaline conditions $\mathrm{pH}$ 8.0 (Ostgaard et al. 1993; Ziayoddin et al. 2012, 2014). Carrageenase from Bacillus sp. Lc50-1 has an optimal activity at $75{ }^{\circ} \mathrm{C}$ and a pH of 8.0 is useful for applications where high concentration of carrageenan is required because at high temperature it is more soluble as well as more oligosaccharides production ( $\mathrm{Li}$ et al. 2014b).

Various metal ions and reagents affect carrageenase activities differently in bacteria. A common trend has been recognized, in most of the cases enzyme activity was negatively affected by heavy metals like $\mathrm{Hg}^{2+}, \mathrm{Co}^{2+}, \mathrm{Zn}^{2+}$, $\mathrm{Cu}^{2+}, \mathrm{Ag}^{1+}, \mathrm{Pb}^{2+}$ which indicated that carrageenase activity is cation independent and they were able to alter the enzyme conformation (Araki et al. 1999; Ma et al. 2010; Shangyong et al. 2013; Li et al. 2015). The inhibition by mercuric ions may indicate the importance of thiol containing amino acid residues in the carrageenase function $(\mathrm{Li}$ et al. 2015). However, metals like $\mathrm{Na}^{+}, \mathrm{K}^{+}, \mathrm{Ca}^{2+}, \mathrm{Mg}^{2+}$ are known to increase the carrageenase activity (Ma et al. 2010; Shangyong et al. 2013; Li et al. 2014b) especially $\mathrm{Na}^{1+}$ at high concentration (up to $500 \mathrm{mmol} \mathrm{L}^{-1}$ ) significantly increase the activity (Ma et al. 2013). It was hypothesized that at high concentration it changes the physical condition of carrageenan would have an effect on enzyme reaction. Nevertheless, carrageenan decomposition around the colony was visible on the carrageenan plate which contained $3 \% \mathrm{NaCl}$ as a component of artificial sea water medium [ASW] (Sarwar et al. 1983a, b). Reagents such as EDTA, Iodoacetic acid and Tween-80 did not affect too much to the enzyme activity (Sarwar et al. 1983a; Li et al. 2015).

Kinetics of mannan depolymerization, i.e., MichaelisMenten constant $\left(K_{\mathrm{m}}\right)$ and the maximal reaction velocity $\left(V_{\max }\right)$ values have been reported for different bacterial carrageenases (Potin et al. 1991; Feixue et al. 2010; Ma et al. 2010). $K_{\mathrm{m}}$ and $V_{\max }$ values reported for Pseudoalteromonas porphyrae LL-1 using $\kappa$-carrageenan as a substrate were $4.4 \mathrm{mgml}^{-1}$ and $0.1 \mathrm{mgmin}^{-1} \mathrm{ml}$, respectively (Liu et al. 2011) and for Pseudomonas elongata MTCC 5168 were $6.7 \mathrm{mgml}^{-1}$ and $4 \mu \mathrm{mol} \mathrm{min}{ }^{-1} \mathrm{mg}$ with same substrate (Khambhaty et al. 2007b). Studies on the production conditions and properties of important carrageenan degraders reported in the recent years have been summarized in Table 2.

\section{Cloning and expression of the carrageenase gene}

Till the advent of recombinant DNA technology, enzymes were produced by fermentation of the microorganisms that express the enzymes. Purification of target enzymes from a pool of proteins requires tedious purification steps thereby increasing their costs. Recombinant DNA technology allows large scale expression of carrageenases in heterologous protein expression hosts. In recent years, a number of studies have been published on the cloning and manipulation of bacterial carrageenases genes from new and previously reported organisms with the aim of enzyme overexpression, analyzing the primary structure of the protein and protein engineering for the alteration of the enzyme properties to suit its commercial applications (Chauhan et al. 2014b, c, d, e) (Table 3).

The gene encoding carrageenase enzyme cloned from various bacteria has been expressed in E. coli in majority of the report available in literature (Guibet et al. 2007; Kobayashi et al. 2012; Liu et al. 2013). However, some genes have been expressed into other hosts also like Bacillus subtilis (Hatada et al. 2011).

Carrageenase production has been increased through heterologous expression in a number of cases (Michel et al. 2001b). High levels of expression has been achieved by cloning the Microbulbifer thermotolerans JAMB-A94 ${ }^{\mathrm{T}}$ carrageenase gene in the heterologous host (Bacillus subtilis) yielding activity of $10^{5} \mathrm{Ul}^{-1}$ which is about 200 fold higher (Hatada et al. 2011). Some genetic engineering has also been done by researcher to scale up the production of carrageenase. The production of carrageenase from $\mathrm{Zo}$ bellia sp. ZM-2 was increased up to 9 times using the natural signal peptide of native strain as well as removing the amino acids of about $20 \mathrm{kDa}$ from C-terminal end of the gene (post translational modification) and expressing it in E. coli (Liu et al. 2013). In addition to this specific activity of carrageenase was also increased to some extent when they were expressed in heterologous hosts (Hatada et al. 2011; Liu et al. 2013). Cloning and expression strategies for different carrageenases have been summarized in Table 3 which might be helpful for planning future strategies for studying the carrageenases at the molecular level.

\section{Application of carrageenases}

The broad substrate specificities of carrageenases have attracted a great deal of attention in the last decade because of their biotechnological potential in various industrial processes. The following section will discuss some of the 


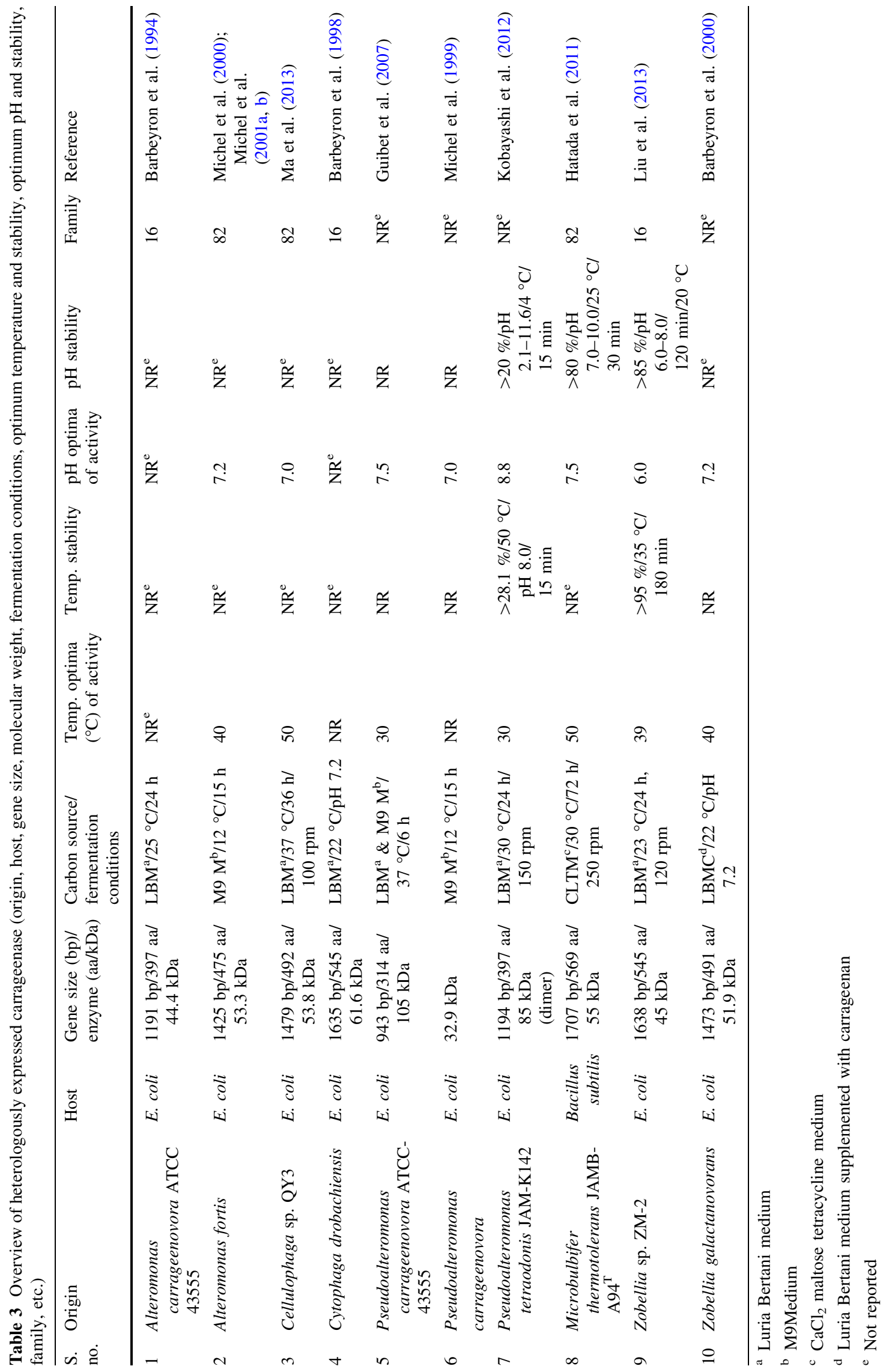




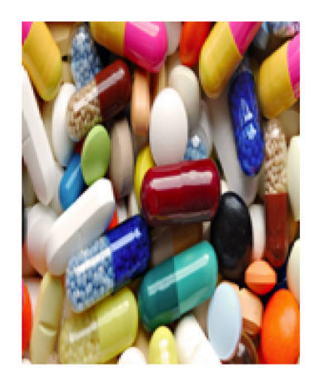

Antitumor agent

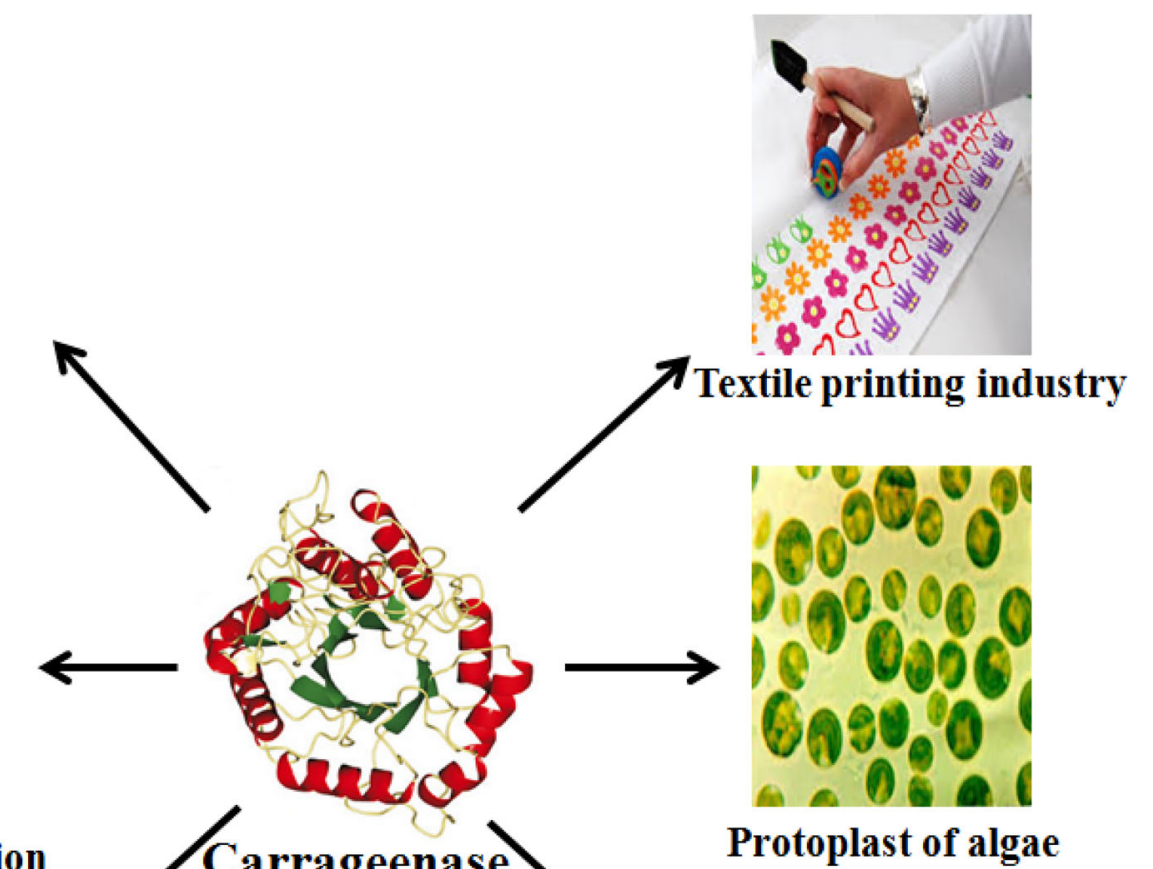

Bioethanol production

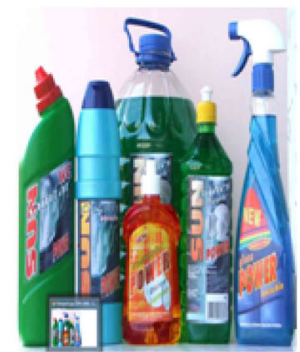

Detergent additives

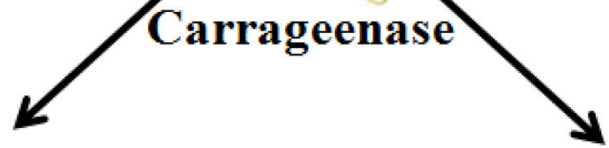

Other applications

Fig. 6 Multifarious applications of carrageenase

most promising and newly explored applications of carrageenases (Fig. 6).

\section{In medical as antitumor agent}

To improve the physical properties of polysaccharides, conversion to oligosaccharide may be the best choice. Hydrolysis products of carrageenan i.e., carragenooligosaccharides have potential anti-tumor properties (Yuan et al. 2006). As discussed in the section of "Enzymatic hydrolysis of carrageenan", oligosaccharides generated by the enzymatic hydrolysis of the carrageenan are more uniform in size rather than chemical hydrolysis which further enhance their anti tumor property. It was reported that the low-molecular-weight carrageenan was effective on the anti-tumor activity, suggesting the molecular weight of oligosaccharides may play an important role (Haijin et al. 2003; Yuan and Song 2005). In addition to this bioactivity of oligosaccharides depends on several other structural features such as the degree of sulfation (DS), the sulfation position, type of sugar, and glycosidic branching. It was hypothesized that the carrageenan oligosaccharides destabilize the interaction between the glucosaminoglycan portion of proteoglycans and the extracellular matrices proteins, thus eliminating the adhesion of cancer cells to matrices, which is necessary in metastasis spread (Yuan et al. 2011).

Haijn et al. (2003) showed that carrageenan oligosaccharide with a molecular weight of 1726 , administered orally at a dose of $100 \mathrm{mg} \mathrm{kg}^{-1}$ in mouse markedly inhibited tumor formation. However, the anti-tumor activity of high-sulfonated carrageenan was much less than that of the non-sulfonated or light-sulfonated preparation. The activities of the latter products on superoxide dismutase and catalase were enhanced considerably, which suggests that carrageenan oligosaccharide was effective in promoting the antioxidation ability and eliminating danger from free radicals. 


\section{Recycling of sea weed waste into bioethanol production}

Seaweeds are suitable for consumption by human beings and animals, and are a favorite food in Asian countries in particular. They are often used in fertilizers, fungicides, herbicides, and phycocolloids such as alginate, carrageenan, and agar (Kim et al. 2011). Worldwide consumption of seafood including seaweeds has increased steadily because of the associated health benefits. In recent years, the amount of seaweed waste has increased because of its use as an industrial resource and as a depolluting plant for cleaning inland sea areas and eutrophied seawater (Tang et al. 2011). Accordingly, the disposal and reuse of seaweed waste has become essential for the preservation of the marine environment and recycling of organic substances. The major species were brown seaweed and red seaweed, such as Porphyra tenera and Porphyra yezoensis. The carbohydrate content of red seaweed is $30-60 \%$, consisting mostly of agar and carrageenan. Unused seaweed waste is customarily discarded via landfill, incineration, or by dumping into the sea which also create environmental pollution. Kang and Kim (2015) isolated a Bacillus sp. SYR4 which were able to utilize sea weed waste as a carbon source by degrading both agar and carrageenan and produced reducing sugars which serves as a substrate for bioethanol production leading to $7-10 \mathrm{wt} \%$ of ethanol could be produced by the isolate.

\section{Use as a detergent additive}

Carrageenans are used in dairy food products such as ice cream, yogurt, flavored milks, whipped toppings, puddings, cheeses, sour cream, juices, ready to spread icings, jams, jellies, salad dressing, candies where it use as a texture modification. In most of the food products, kappa carrageenan presents either, alone or in combination with another type of carrageenan which can cause laundry stains (Aronson et al. 2001). As carrageenans have a high affinity for cellulose fibers, therefore, they adsorb these stains to the fabric very tightly because they are not easy to remove. Polysaccharide degrading enzymes, like carrageenase, can be used as laundry additives to hydrolyze the gums present in these food stains. McDonald and Schmidt (2009) have formulated detergent composition (fabric cleaning compositions, surface cleaning compositions, oral cleaning compositions, contact lens cleaning compositions, dish cleaning compositions) containing combination of carrageenase (about 1-80\%) and surfactant (cationic, anionic or mixture thereof) which are able to hydrolyze polysaccharides efficiently hence removing the gum containing stains and giving excellent cleaning properties.

\section{Removal of excess printing paste after textile printing}

In printing of textiles, it is common to use a printing paste containing a dye and a thickener. Among the commonly used thickeners are biological polymers (alginate, starch or modified starch, locust bean gum, galactomannan or modified galactomannan and carboxymethyl cellulose). With most printing methods, the polymer and excess dye must be removed by washing with water after the fixation of the print. Generally, a large amount of water is required for complete removal due to the high viscosity and low water solubility of the printing paste. Insufficient removal leads to unsatisfactory quality of the finished textile for the following reasons: (1) dye may be transferred to other parts of the printed textile or to other garments during laundering by the consumer. (2) Residual thickener will make printed areas stiff (Salem et al. 2008).

Pedersen et al. (1995) reported that composition comprising carrageenase along with other polysaccharide degrading enzymes will decrease process time as well as the amount of energy and water needed to achieve a satisfactory quality of the textile by hydrolyzing these polymers.

\section{For isolation of protoplast of algae}

Carrageenases can be used for the isolation of protoplast of algae along with other cell wall degrading enzymes such as Cellulase and Macerozyme. This isolated protoplast can be used for genetic engineering experiments for the production of improved algal strains yielding better quality carrageenan of commercial value (Chen et al. 1994).

Khambhaty et al. (2007b) showed the role of bacterial carrageenase (Pseudomonas elongata MTCC 5168) in isolation of protoplast of red algae Kappaphycus alvarezii. They demonstrated that carrageenase in combination with commercially available Cellulase and Macerozyme yielded protoplast from $K$. alvarezii where in absence of $\kappa$-carrageenase, did not yield protoplasts. Morover presence or absence of individual enzymes, the composition of the osmoticum and the age of tissue were instrumental for protoplast yields (Zablackis et al. 1993). 


\section{Other applications}

\section{Prevent red algal bloom}

The enzymes produced by marine bacteria could effectively control red algal bloom contamination. Thus, it prevents bio fouling of submerged marine surface or pipes by acting on complex polysaccharide layers (Khambhatya et al. 2007c).

\section{Used in structural functional studies}

Carrageenases provide the opportunity to investigate the structure-function relationships of the hydrolases that degrade self-associating sulfated polysaccharides (Michel et al. 2001a).

\section{Protein extraction form the cell wall}

Most red seaweed possesses high level of proteins (10-30 \% dry weight) (Morgan et al. 1980). These proteins can be extracted by hydrolytic enzymes like carrageenase (Fleurence et al. 1995). For example, the degradation of cell Wall polysaccharides by hydrolytic enzymes is used for the isolation of extensin, a protein linked to cell wall polysaccharide of higher plants (Lamport 1969).

\section{Conclusion}

Microbial carrageenases have attracted great attention in near past because of their useful applications. Such enzyme systems are not only of academic interest since they have potential biotech applications in a wide range of industrial enzyme markets. Exploitation of biodiversity to provide microorganisms that produce carrageenases well suited for their diverse applications is considered to be one of the most promising future alternatives. The knowledge summarized in this review, regarding the known sources of carrageenases, and their properties would be a great help to study these enzymes, so that they can be effectively utilized for various biotechnological processes.

\section{Acknowledgments This study is funded by Department of Educa- tion, Employment and Workplace Relations, (DEEWR) Australian government (Grant No. ERF_PDR_128381_2014/4478_2015). Prak- ram Singh Chauhan is highly thankful to Australian Government for providing Endeavour Post Doctoral Research Fellowship.}

\section{Compliance with ethical standards}

Conflict of interest The authors declare that they have no conflict of interest.
Human and animal rights and informed consent Research involving Human Participants and/or Animals/Informed consent: not applicable for this study.

Open Access This article is distributed under the terms of the Creative Commons Attribution 4.0 International License (http:// creativecommons.org/licenses/by/4.0/), which permits unrestricted use, distribution, and reproduction in any medium, provided you give appropriate credit to the original author(s) and the source, provide a link to the Creative Commons license, and indicate if changes were made.

\section{References}

Araki T, Higashimoto Y, Morishita T (1999) Purification and characterization of kappa carrageenase from a marine bacterium, Vibrio CA-1004. Fish Sci 65(6):937-942

Aronson MP, Brown CP, Chatfield RJ, Willis E (2001) Aqueous detergent compositions thickened using carrageenan. US Patent 6265368B1

Barbeyron T, Henrissat B, Kloareg B (1994) The gene encoding the $\kappa$-carrageenase of Alteromonas carrageenovora is related to $\beta$ 1,3-1,4-glucanases. Gene 139:105-109

Barbeyron T, Gerard A, Potin P, Henrissat B, Kloareg B (1998) The $\kappa$-carrageenase of the marine bacteriumCytophaga drobachiensis. Structural and phylogenetic relationships within family-16 glycoside hydrolases. Mol Biol Evol 15:528-537

Barbeyron T, Michel G, Potin P, Henrissat B, Kloareg B (2000) 1Carrageenases constitute a Novel Family of glycoside hydrolases, unrelated to that of $\kappa$-Carrageenases. J Biol Chem 275(45):35499-35505

Bellion C, Hamar GK, Yaphe W (1982) The degradation of Eucheuma spinosum and Eucheuma cottinii carrageenans by 1carrageenases and $\kappa$-carrageenases from marine bacteria. Can $\mathbf{J}$ Microbiol 28:874-884

Beltagy EA, Youssef AS, El-Shenaway MA, El-Assar SA (2012) Purification of kappa ( $\kappa)$-carrageenase from locally isolated Cellulosimicrobium cellulans. Afr J Biotechnol 11(52):11438-11446

Bras FN, Fernandes PA, Ramos MJ, Cerqueira NMFSA (2012) Glycosidases-A Mechanistic Overview. In: Chang CF (ed) Comprehensive studies on Glycobiology and Glycotechnology. INTECH, pp 117-134

Campo VL, Kawano DF, Silva DBD, Carvalho I (2009) Carrageenans: biological properties, chemical modifications and structural analysis-a review. Carbohydr Polym 77:167-180

Cantarel BL, Coutinho PM, Rancurel C, Bernard T, Lombard V, Henrissat B (2009) The carbohydrate-active enzymes database (CAZy): an expert resource for Glycogenomics. Nucleic Acids Res 37:D233-D238

Chauhan PS, Gupta N (2016) Insight into microbial mannosidase: a review. Cri Rev Biotechnol 8:1-12

Chauhan PS, Puri N, Sharma P, Gupta N (2012) Mannanases: microbial sources, production, properties and potential biotechnological applications. Appl Microbiol Biotechnol 93:1817-1830

Chauhan PS, George N, Sondhi S, Puri N, Gupta N (2014a) An overview of purification strategies for microbial mannanases. Int J Pharma Bio Sci 5:176-192

Chauhan PS, Sharma P, Puri N, Gupta N (2014b) Purification and characterization of an alkali-thermostable $\beta$-mannanase from Bacillus nealsonii PN-11 and its application in manno-oligosaccharides preparation having prebiotic potential. Eur Food Res Technol 238:927-936 
Chauhan PS, Sharma P, Puri N, Gupta N (2014c) A process for reduction in viscosity of coffee extract by enzymatic hydrolysis of mannan. Bioproc Biosyst Eng 37:1459-1467

Chauhan PS, Soni SK, Sharma P, Saini A, Gupta N (2014d) A mannanase from Bacillus nealsonii PN-11: statistical optimization of production and application in biobleaching of pulp in combination with xylanase. Int J Pharma Bio Sci 5:237-251

Chauhan PS, Bharadwaj A, Puri N, Gupta N (2014e) Optimization of medium composition for alkali-thermostable mannanase production by Bacillus nealsonii PN-11 in submerged fermentation. Int J Curr Microbiol Appl Sci 3(10):1033-1045

Chauhan PS, Tripathi SP, Sangamwar AT, Puri N, Sharma P, Gupta N (2015) Cloning, molecular modeling and docking analysis of alkali-thermostable $\beta$-mannanase from Bacillus nealsonii PN-11. Appl Microbiol Biotechnol 99:8917-8925

Chen LCM, Craigie JS, Xie ZK (1994) Protoplast production from Porphyra linearis using a simplified agarase procedure capable of commercial application. J Appl Phycol 6:35-39

Coutinho PM, Henrissat B (1999) An integrated databas approach. In: Gilbert HJ, Davies G, Henrissat B, Svensson B (eds) Recent advances in carbohydrate bioengineering. The Royal Society of Chemistry, Cambridge, pp 3-12

Davies GJ, Wilson KS, Henrissat B (1997) Nomenclature for sugarbinding subsites in glycosyl hydrolases. Biochem J 321:557-559

Dygert S, Li LH, Florida D, Thoma JA (1965) Determination of reducing sugar with improved precision. Anal Biochem 13(3):367-374

Dyrset N, Lystad KQ, Levine DW (1997) Development of a fermentation process for production of a $\kappa$-carrageenase from Pseudomonas carrageenovora. Enzyme Microb Technol 20:418-423

Feixue S, Yuexin MA, Ying W, Qian L (2010) Purification and characterization of novel $\kappa$-carrageenase from marine Tamlana sp. HC4. Chin J Ocean Limnol 28:1139-1145

Fleurence J, Massiani L, Guyader O, Mabeau S (1995) Use of enzymatic cell Wall degradation for improvement of protein extraction from Chondrus crispus, Gracilaria verrucosa and Palmaria palmale. J Appl Phycol 7:393-397

George N, Chauhan PS, Kumar V, Puri N, Gupta N (2014a) An approach to ecofriendly leather: lime and sulphide free dehairing of skin and hide using bacterial alkaline protease at industrial scale. J Clean Prod 79:249-257

George N, Chauhan PS, Puri N, Gupta N (2014b) Statistical optimization of process parameters for production of alkaline protease from Vibrio metschnikovii NG155 having application in leather industry. Int J Pharma Bio Sci 5:509-517

Greer CW, Yaphe W (1984) Purification and properties of iotacarrageenase from a marine bacterium. Can J Microbiol 30:1500-1506

Guibet M, Barbeyron T, Genicot S, Kloareg B, Michel G (2007) Degradation of $\lambda$-carrageenan by Pseudoalteromonas carrageenovora $\lambda$-carrageenase: a new family of glycoside hydrolases unrelated to $\kappa-$ and $\mathrm{t}$-carrageenases. Biochem J 114:105-114

Haijin M, Xiaolu J, Huashi G (2003) A $\kappa$-carrageenan derived oligosaccharide prepared by enzymatic degradation containing anti-tumor activity. J Appl Phycol 15:297-303

Hatada Y, Mizuno M, Li Z, Ohta Y (2011) Hyper-production and characterization of the 1-carrageenase useful for i-carrageenan oligosaccharide production from a deep-sea bacterium, Microbulbifer thermotolerans JAMB-A94T, and insight into the unusual catalytic mechanism. Mar Biotechnol 13:411-422

Henares BM, Enriquez EP, Dayrit FM, Rojas NRL (2010) Iotacarrageenan hydrolysis by Pseudoalteromonas carrageenovora IFO12985. Philipp J Sci 139(2):131-138

Hilliou L, Larotonda FDS, Abreu P, Ramos AM, Sereno AM, Goncalves MP (2006) Effect of extraction parameters on the chemical structure and gel properties of $\kappa / \mathrm{l}$-hybrid carrageenans obtained from Mastocarpus stellatus. Biomol Eng 23:201-208

Jam M, Flament D, Allouch J, Potin P, Thion L, Kloareg B, Czjzek M, Helbert W, Michel G, Barbeyron T (2005) The endo- $\beta$-agarases AgaA and AgaB from the marine bacterium Zobellia galactanivorans: two paralogue enzymes with different molecular organizations and catalytic behaviours. Biochem J 385:703-713

Kang S, Kim JK (2015) Reuse of seaweed waste by a novel bacterium, Bacillus sp. SYR4 isolated from a sandbar. World J Microbiol Biotechnol 31(1):209-217

Khambhaty Y, Mody K, Jha B (2007a) Purification and characterization of $\kappa$-carrageenase from a novel $\gamma$-proteobacterium, Pseudomonas elongata (MTCC 5261) syn. Microbulbifer elongatus comb. Nov. Biotechnol Bioprocess Eng 12:668-675

Khambhaty YN, Mody KH, Jha B (2007c) Method for the preparation of $\kappa$-carrageenase. US 2007/0231866A1

Khambhatya Y, Mody K, Jha B, Gohel V (2007) Statistical optimization of medium components for $\kappa$-carrageenase production by Pseudomonas elongate. Enzyme Microb Technol 40:813-822

Kidby DK, Davidson DJ (1973) A convenient ferricyanide estimation of reducing sugars in the nanomole range. Anal Biochem 55(1):321-325

Kim JH, Kim YH, Kim SK, Kim BW, Nam SW (2011) Properties and industrial applications of seaweed polysaccharides-degrading enzymes from the marine microorganisms. Korean J Microbiol Biotechnol 39:189-199

Knudsen NR, Ale MT, Meyer AS (2015) Seaweed hydrocolloid production: an update on enzyme assisted extraction and modification technologies. Mar Drugs 13:3340-3359

Kobayashi T, Uchimura K, Koide O, Deguchi S, Horikoshi K (2012) Genetic and Biochemical characterization of Pseudoalteromonas tetraodonis alkaline $\kappa$-carrageenase. Biosci Biotechnol Biochem 76(3):506-511

Lamport DTA (1969) The isolation and partial characterization of hydroxyproline rich glycolipides obtained by enzymic degradation on primary cell walls. Biochemistry $3: 1155-1163$

Lemoine M, Nyvall Collén P, Helbert W (2009) Physical state of kappa-carrageenan modulates the mode of action of kappacarrageenase from Pseudoalteromonas carrageenovora. Biochem J 419:545-553

Li J, Hu Q, Seswita-Zilda D (2014a) Purification and characterization of a thermostable $\lambda$-carrageenase from a hot spring bacterium, Bacillus sp. Biotechnol Lett 36(8):1669-1674

Li L, Ni R, Shao Y, Mao S (2014b) Carrageenan and its applications in drug delivery. Carbohydr Polym 103:1-11

Li Y, Huang Z, Qiao L, Gao Y, Guan H, Hwang H, Aker WG, Wang $P$ (2015) Purification and characterization of a novel enzyme produced by Catenovulum sp. LP and its application in the pretreatment to Ulva prolifera for bio-ethanol production. Process Biochem 50(5):799-806

Liu GL, Li Y, Chi Z, Chi ZM (2011) Purification and characterization of $\kappa$-carrageenase from the marine bacterium Pseudoalteromonas porphyrae for hydrolysis of $\kappa$-carrageenan. Process Biochem 46:265-271

Liu Z, Li G, Mo Z, Mou H (2013) Molecular cloning, characterization, and heterologous expression of a new $\kappa$-carrageenase gene from marine bacterium Zobellia sp. ZM-2. Appl Microbiol Biotechnol 97:10057-10067

Liu Z, Tian L, Chen Y, Mou H (2014) Efficient extracellular production of $\kappa$-carrageenase in Escherichia coli: effects of wild type signal sequence and process conditions on extracellular secretion. J Biotechnol 185:8-14

Liu G, Wu S, Jin W, Sun C (2016) Amy63, a novel type of marine bacterial multifunctional enzyme possessing amylase, agarase and carrageenase activities. Sci Rep. doi:10.1038/srep18726 
Ma YX, Dong SL, Jiang XL, Li J, Mou HJ (2010) Purification and characterization of $\kappa$-carrageenase from marine bacterium mutant strain Pseudoalteromonas sp. AJ5-13 and its degraded products. J Food Biochem 34:661-678

Ma S, Duan G, Chai W, Geng C, Tan Y, Wang L, Sourd F, Michel G, Yu W, Han F (2013) Purification, cloning, characterization and essential amino acid residues analysis of a New 1-carrageenase from Cellulophaga sp. QY3. PlosOne 8(5):e64666

McDonald HC, Schmidt B (2009) Kappa-carrageenase and kappacarrageenase containing compositions. US20090048136A1

Mclean MW, Williamson FB (1979) Kappacarrageenase from Pseudomonas carrageenovora. Eur J Biochem 93(3):553-558

Michel AS, Mestdagh MM, Axelos MA (1997) Physico-chemical properties of carrageenan gels in presence of various cations. Int J Biol Macro 21:195-200

Michel G, Barbeyron T, Flament D, Vernet T, Kloareg B, Dideberg O (1999) Expression, purification, crystallization and preliminary $\mathrm{X}$-ray analysis of the $\mathrm{\kappa}$-carrageenase from Pseudoalteromonas carrageenovora. Acta Cryst D55:918-920

Michel G, Flament D, Barbeyron T, Vernet T, Kloareg B, Dideberg O (2000) Expression, purification, crystallization and preliminary $\mathrm{X}$-ray analysis of the iota-carrageenase from Alteromonas fortis. Acta Crystallogr Sect D Biol Crystallogr 56:766-768

Michel G, Chantalat L, Duee E, Barbeyron T, Henrissat B, Kloareg B, Dideberg O (2001a) The kappa-carrageenase of $P$. carrageenovora features a tunnel-shaped active site: a novel insight in the evolution of Clan-B glycoside hydrolases. Structure 9:513-525

Michel G, Chantalat L, Fanchon E, Henrissat B, Kloareg B, Dideberg $\mathrm{O}(2001 \mathrm{~b})$ The 1-carrageenase of Alteromonas fortis. A $\beta$-helix fold-containing enzyme for the degradation of a highly polyanionic polysaccharide. J Biol Chem 276:40202-40209

Michel G, Helbert W, Kahn R, Dideberg O, Kloareg B (2003) The structural bases of the processive degradation of $l$-carrageenan, a main cell wall polysaccharide of red algae. J Mol Biol 334:421-433

Michel G, Nyval-Collen P, Barbeyron T, Czjzek M, Helbert W (2006) Bioconversion of red seaweed galactans: a focus on bacterial agarases and carrageenases. Appl Microbiol Biotechnol $71: 23-33$

Miller GL (1959) Use of dinitrosalicylic acid reagent for determination of reducing sugars. Anal Chem 31:426-428

Morgan C, Wright JLC, Simpson J (1980) Review of chemical constituents of the red alga Palmaria palmale (dulse). Econ Bot $34: 27-50$

Mou H, Jiang X, Liv Z, Guan H (2004) Structural analysis of kappacarrageenan oligosaccharides released by carrageenase from marine Cytophaga MCA-2. J Food Biochem 28:245-260

Necas J, Bartosikova L (2013) Carrageenan: a review. Vet Med 58(4):187-205

Ohta Y, Hatada Y (2006) A novel enzyme, lambda-carrageenase isolated from a deep sea bacterium. J Biochem 140(4):475-481

Ostgaard K, Wangen BF, Knutsen SH, Aasen IM (1993) Large-scale production and purification of a-carrageenase from Pseudomonas carrageenovora for application in seaweed biotechnology. Enzyme Microb Technol 15:326-333

Pedersen G, Hagen HA, Asferg L, Sorensen E (1995) Removal of printing paste thickner and excess dye after textile printing. US5405414A

Potin P, Sanseau A, Le Gall Y, Rochas C, Kloareg B (1991) Purification and characterization of a new $\kappa$-carrageenase from a marine Cytophaga-like bacterium. Eur J Biochem 201:241-247

Potin P, Richard C, Barbeyron T, Henrissat B, Gey C, Petillot Y, Forest E, Dideberg O, Rochas C, Kloareg B (1995) Processing and hydrolytic mechanism of the $c g k A$-encoded $\kappa$-carrageenase of Alteromonas carrageenovora. Eur J Biochem 228:971-997
Rebuffet E, Barbeyron T, Jeudy A, Jam M, Czjzek M, Michel G (2010) Identification of catalytic residues and mechanistic analysis of family GH82 iota-carrageenases. Biochemistry 49:7590-7599

Rowe RC, Sheskey PJ, Quinn ME (2009) Handbook of Pharmaceutical Excipients. Am Pharm Assoc Pharm Press, London

Ruiter GAD, Rudolph B (1997) Carrageenan biotechnology. Trends Food Sci Technol 8:389-395

Salem AA, Nassar SH, Rekaby MM (2008) Improving the removal of printing paste thickener and excess dye by enzymatic washing of printed cotton fabrics. J Nat Fibers 5(1):1-18

Sarwar G, Sakata T, Kakirriotom D (1983a) Isolation and characterization of carrageenan-decomposing bacteria from marine environment. J Gen Appl Microbiol 29:145-155

Sarwar G, Sakata T, Kasimoto D (1983b) The production and characteristic of carrageenase from Cytophaga. Bull Jpn Soc Sci Fish 49:1689-1694

Sarwar G, Matayoshi S, Oda H (1987) Purification of א-carrageenase from marine Cytophaga species. Microbiol Immunol 31:869-877

Shangyong LI, Panpan JIA, Linna W, Wengong YU, Feng H (2013) Purification and characterization of a new thermostable $\kappa$ carrageenase from the marine bacterium Pseudoalteromonas sp. QY203. J Ocean Univ China 12(1):155-159

Somogyi M (1952) Notes on sugar determination. J Biol Chem 195:19-23

Sondhi S, Sharma P, George N, Chauhan PS, Puri N, Gupta N (2015) A Novel Extracellular Thermo-Alkali-Stable Laccase from Bacillus tequilensis SN4 having potential to biobleach softwood pulp. 3Biotech 5:175-185

Tang J, Wang M, Zhou Q, Nagata S (2011) Improved composting of Undaria pinnatifida seaweed by inoculation with Halomonas and Gracilibacilus sp. isolated from marine environments. Bioresour Technol 102:2925-2930

Tayco CC, Tablizo FA, Regalia RS, Lluisma AO (2013) Characterization of a $\mathrm{K}$-carrageenase-producing marine bacterium, Isolate ALAB-001. Philipp J Sci 142(1):45-54

Van De Velde F, Peppelman HA, Rollema HS, Hans R (2001) On the structure of $\kappa /$-hybrid carrageenans. Carbohydr Res 331:271-283

Weigl J, Yaphe W (1966) The enzymatic hydrolysis of carrageenan by Pseudomonas carrageenovora: purification of a $\kappa$-carrageenase. Can J Micrbiol 12:939-947

Xiao A, Xu C, Lin Y, Ni H, Zhu Y, Cai H (2016) Preparation and characterization of $\kappa$-carrageenase immobilized onto magnetic iron oxide nanoparticles. Electron J Biotechnol 19:1-7

Xu C, Zhu Y, Ni H, Cai H, Li L, Xiao A (2015) Isolation, identification of a $\kappa$-carrageenase-producing bacterium and $\kappa$-carrageenase characterization. Wei Sheng Wu Xue Bao 55(2):140-148

Yao Z, Wang F, Gao Z, Jin L, Wu H (2013) Characterization of a $\kappa$ carrageenase from marine Cellulophaga lytica strain N5-2 and analysis of its degradation products. Int J Mol Sci 14:24592-24602

Yao Z, Wu H, Zhang S, Du Y (2014) Enzymatic preparation of $\kappa-$ carrageenan oligosaccharides and their anti-angiogenic activity. Carbohydr Polym 30(101):359-367

Yaphe W, Baxter B (1955) The enzymic hydrolysis of carrageenan. Appl Microbiol 3:987-993

Youssef AS, Beltagy EA, El-Shenawy MA, El-Assar SA (2012) Production of $\kappa$-carrageenase by Cellulosimicrobium cellulans isolated from Egyptian Mediterranean coast. Afr J Microbiol Res 6(37):6618-6628

Yuan HM, Song JM (2005) Preparation, structural characterization and in vitro antitumor activity of kappa-carrageenan oligosaccharide fraction from Kappaphycus striatum. J Appl Phycol 17:7-13

Yuan HM, Song JM, Li XG, Li N, Dai JC (2006) Immunomodulation and antitumor activity of $\kappa$-carrageenan oligosaccharides. Cancer Lett 243:228-234 
Yuan H, Song J, Li X, Li N (2011) Enhanced immunostimulatory and antitumor activity of different derivatives of $\kappa$-carrageenan oligosaccharides from Kappaphycus striatum. J Appl Phycol 23:59-65

Zablackis E, Vreeland V, Kloareg B (1993) Isolation of protoplasts from Kappaphycus alvarezii var. tambalang (Rhodophyta) and secretion of $\kappa$-carrageenan fragments by cultured cells. J Exp Bot 44:1515-1522

Zhou MH, Ma JS, Li J, Ye H, Huang K, Zhao X (2008) A kappacarrageenase from a newly isolated Pseudoalteromonas-like bacterium, WZUC10. Biotechnol Bioprocess Eng 13:545-551
Zhu B, Ning L (2016) Purification and characterization of a New אcarrageenase from the marine bacterium Vibrio sp. NJ-2. J Microbiol Biotechnol 26(2):255-262

Ziayoddin M, Shinde M, Lalitha J (2012) Orthogonal array approach for optimization of carrageenase production by solid state fermentation of Pseudomonas aeruginosa ZSL-2. J Microb Biochem Technol 4:4

Ziayoddin M, Lalitha J, Shinde M (2014) Increased production of carrageenase by Pseudomonas aeruginosa ZSL-2 using Taguchi experimental design. Int Lett Nat Sci 17:194-207 